\title{
ALLEN NEWELL: AN ADIEU
}

\author{
A.D. de Groot \\ Emeritus Professor \\ Universities of Amsterdam and Groningen
}

In Allen Newell's early death, two worlds have lost a great man. Computer technology is the worse for his passing and so is cognitive science for losing an important scientist and a striking personality.

There is no need here to list his merits, which have been highlighted by a plethora of awards. The seventies saw him distinguished by august bodies in computer technology and information processing. But also the Human Factor Society and the American Psychological Association have honoured him, the latter with the Gold Medal for his collected oeuvre. In 1989, the University of Groningen granted him an Honorary Doctorate, distinguishing itself, I feel, no less than the recipient. These are but a few cases out of a long series witnessing the two main elements in Allen Newell's interests and achievements. It was round about 1955 that he broached the main theme of his scientific career: the discovery and reconstruction by computer simulation of the mechanisms of the human mind.

Allen Newell was educated in an intellectual environment. His father taught radiology at Stanford University's Medical School, then located at San Francisco where he grew up. A decisive event came early in his life: at age sixteen he fell in love with a fellow student, Noel McKenna, whom he married at age twenty; their marriage was dissolved only by his untimely death. After his military service, he enrolled as a veteran at Stanford University with physics as his major subject, continuing in Princeton. It was there he discovered he was not a 'born' mathematician; he did not finish Graduate School, but managed, instead, to obtain employment certainly at least as interesting with the Santa Monica-based Rand Corporation, just barely established at the time.

Here, his fertility showed itself at once: he saw the possibilities of non-numerical programming and of computer simulation in a research project intent on analyzing the flow of information through persons in an organization. On the basis of this work, much later honoured by his Human Factor Society Award (1976), he was entitled to join the APA in 1952, which involved his being recognized as a psychologist.

While with the Rand Corporation, he met Herbert Simon, then a consultant there. This led to the decision that Newell would graduate under Simon at the CIT (Carnegie Institute of Technology, later the Carnegie-Mellon University) as a Ph.D. The date of its happening was 1957 in what was then a relative newcomer, the 'Graduate School in Industrial Administration' - an appellation hardly likely to make one suspect that this School would also be among the centers of the so-called cognitive revolution in psychology. Though Newell was still formally with the Rand Corporation up to 1961 - on loan to Carnegie Tech - we can confidently designate 1955 as the year starting the long and fertile cooperation with Simon.

It is not here the place to specify that most productive joint undertaking, nor to detail the impact of Newell's subsequent work. Its history is now a matter of common knowledge and has been recorded in the long list of Newell's publications. Analysis of that work is best left to persons more competent in artificial intelligence. Rather, I would make room for some of my personal impressions and reminiscences.

In 1954, a letter reached me from Herbert Simon - then completely unknown to me - in which he told me that he had read my book in the original Dutch (De Groot, 1946). The letter invited me to drop in on him 'if I should be in the States'. As it happened, this was in April 1955 and I could carve a day out of my programme with social psychologists in order to visit Carnegie Tech. The main point on their agenda was their writing a chessplaying computer program.

During Simon's introduction to the subject, Newell was seated next to him, silent at first; he was balding but evidently still young. However, he became highly articulate when the technical points of the simulation came up: unstoppable, talking nineteen to the dozen, somewhat slurring his speech and couching the whole in a computer jargon which, even after amplification, was only half-understandable to me. It was heavy going (especially because the night before I had lost most of my sleep since I had been snared into taking an overnight 
train to Pittsburgh). After their exposé I recall saying: "So far, I am with you: a program able to play chess. However, I am much more interested in human thought and what computer programming can do to help in building theories about that."

The answer, nearly unisono from both of them, surprised me most agreeably: "But that is our aim too!" From that moment onward, it was clear we were in harmony. The remainder of the day I mostly spent with Herbert Simon, but that same evening, at the Faculty Club, I had an opportunity to deepen my acquaintance with Allen Newell. I learned to appreciate him, not only as a very clever and inspired scientist, but also as a pleasant conversational partner. The two of them also introduced me to the game 'Kriegspiel' (Can I?): decision making on the chess board under very high uncertainty. Being unfamiliar with the game, I grandly lost.

In 1960, I had the chance to visit Pittsburgh for a couple of days out of Stanford. My friend Nico Frijda, meanwhile interested in computer simulation and happening to be in the States, joined the party. During these days an element of friendship was added to our scientific interaction. Newell was now an important member of staff, 'matured', more articulate, of an easy riposte, and very witty at times, while still retaining his effervescent enthusiasm, his emotional involvement and his inspiration.

In the years to come there was an exchange, by letter, between their work and our project 'Thought and Memory'. Truth to tell, it was a lopsided exchange: at the time we hardly had any computer facilities, let alone expertise in this respect, and certainly could not cope with their incessant stream of preprints.

In 1965 I was invited to talk in Pittsburgh at a conference about our project. Allen Newell meanwhile had moved up on the authority scale, but this did not make him any more subdued and certainly not less informal. I can still visualize him attending a lecture by Skinner (I believe): rather fatter than he used to be, his shirttails protruding over the top of his trousers, sprawling in his chair, his legs leaning on the row in front, but highly 'with it' as the discussion was to prove. He did not mince his words, he was still a rapid-fired speaker, but he did not make enemies: he was strictly honest even when emotionally - sometimes childishly - involved in the subject. Add his humour and one may well picture how disarming he was, for all his fervour in disputes.

Elsa, my wife, had joined me on this occasion, which was when we first met his wife Noel. It is hard to picture a greater contrast between spouses: she petite, fragile and introvert, he huge, somewhat muscle-bound and most extrovert. Yet, their togetherness showed Allen to be quiet, protective and tender, qualities one would hardly expect at first blush.

A few years later I was privileged to meet him again as a speaker in a workshop organized by Max Euwe, and privately as well. In the private contacts, what stands out was a long talk in an Amsterdam café, when he probed my work, my ideas and my plans, with critical questions interspersed. The striking thing was that, for all his volubility, he proved himself to be a good listener as well. Our relationship had grown into a proper friendship, which much later was sealed by a breakfast $a$ quatre in 1980 in Berne, where he presented a superb lecture on the heuristic of George Polya and its relation to artificial intelligence (Newell, 1983).

My last meetings with him were in Groningen, on the occasion of his Honorary Doctorate in 1989 and, shortly afterwards, during the open day of his SOAR course. Was he still the same man? Mostly, I think, he was, but perhaps somewhat spoiled by his fame; at any rate more assured of his own words.

On that open day, I as the concluding speaker had stressed rather strongly my criticism of his approach to human cognition as manipulation of symbols. In my view this can do no justice to holistic processes of perception and intuition. Unfortunately, he was given little time for responding; if memory serves, three minutes was all the chairman gave him. But afterwards Newell told me that he had been able to 'refute all my counterarguments' had he been given time. This was more defensive than I was used to. Had Allen meanwhile grown slightly more rigid as a person, had his health been plaguing him even then? Whatever the reason, it slightly disappointed me that this last meeting, fated to be our last, was not as warm as I had hoped.

However, let this not detract from the memory of an inventive genius, of a workaholic charming by his impetuosity, but also at times by his surprising soft and sensitive sides.

Allen Newell was a great scientist and a fine person - unforgettable to all who knew him. 


\title{
Source and References
}

The above is a translation of De Groot's In Memoriam Allen Newell (1927-1992) as published in the NVKINieuwsbrief, Vol. 9. No. 4, pp. 116-117.

Groot, A.D. de (1946). Het denken van den schaker, een experimenteel-psychologische studie. Ph.D. thesis, University of Amsterdam; N.V. Noord-Hollandse Uitgevers Maatschappij, Amsterdam. Translated, with additions, (in 1965) as Thought and Choice in Chess. Mouton Publishers, The Hague.

Newell, A. (1983). The Heuristic of George Polya and its Relation to Artificial Intelligence. Methods of Heuristics (eds. R. Groner, M. Groner and W.F. Bishoff), pp. 195-243. Erlbaum, Hillsdale, N.J.

\section{LITERATURE RECEIVED}

\section{WISSENSDARSTELLUNG UND -VERARBEITUNG IN STRATEGISCHEN SPIELEN}

\author{
Christian Posthoff, Michael Schlosser and Rainer Staudte \\ Preprint Nr. 218/6. Jg./1992 \\ Fachbereich Informatik \\ Technische Universität Chemnitz \\ 21 pages
}

An English version of the abstract reads:

Strategic games (Draughts/Checkers, Chess, Go etc.) still are a major application area for AI methods, because the evaluation of results is as convenient as a risk-free experiment. Specifically one has to state, for the theories, algorithms and programs created, where they stand between the extremes of the algorithmic and descriptive concepts. The former is based on a small space requirement and intensive computing, the latter on high storage needs and relatively slight computing demands; any point in the spectrum between these extremes may nowadays be aimed at. In order to keep decisions subject to experts' judgement, concepts within the human window are to be preferred.

There is a natural stress in knowledge processing on the construction of rules which may be derived from aggregating single pieces of information. Several procedures for solving this problem are proposed. Applications are on positions in strategic games, for which extensive and generally-known experience is already available, which may not be true for less well-developed areas of knowledge.

\section{COMPUTER-CHESS ARTICLES PUBLISHED ELSEWHERE}

Matthew L. Ginsberg and William D. Harvey (1992). Iterative Broadening. Artificial Intelligence, Vol. 55, pp. 367-383.

\footnotetext{
Abstract - Conventional blind search techniques generally assume that the goal nodes for a given problem are distributed randomly along the fringe of the search tree. We argue that this is often invalid in practice and suggest that a more reasonable assumption is that decisions made at each point in the search carry equal weight. We go on to show that a new search technique called iterative broadening leads to orders-of-magnitude savings in the time needed to search a space satisfying this assumption; the basic idea is to search the space using artificial breadth cutoffs that are gradually increased until a goal is found. Both theoretical and experimental results are presented.
} 